麻酔回路内のフィルターの効用は加温及び加温, 細 菌除去にあるとされているが今回の実験の結果，微小 異物除去の点でも非常に有用であることがわかった。

\section{5. 超長毒命酸来センサの奉命試硂について}

東京大 麻酔科·中央手術部

釘 宮 豊 城

東京大 中央手術部

都 筑 正 和 東京大 麻酔科

稲田

豊

アイカ

山口宣 明

麻酔回路内酸素濃度モニタの必要性は今更言う迄も なく，本モニタの装着実施率は年々高まっている，し なしながら時として，装着されていながら，センサが 寿命切れや機能不全のためスイッチが入れられていな かったり, 電池が切れているのをそのままにしていた りするのを経験している.これは維持整備の覀さとい うことになるが, より根本的にはセンサ寿命の短さ と, 電池寿命の短さが大きな要因として考えられる. 忙しい日常の臨床の場ではセンサおよび電池の寿命は 1 日でも長い方が望ましい.

この要望に対し, 我々は寿命の長い酸素センサと電 池寿命の長い浪度計の開発を急いできた．その結果， 寿命 $1,200,000 \%$ 時間の酸素センサと電池寿命 3000 時間の酸素濃度計の開発に成功し, 昨年の臨床麻酔学 会で発表した。

発表された寿命は加速寿命試験によるものであっ て，実際にセンサを $100 \%$ 酸素中に直いて寿命を測っ たものではなかった. 当然, 実際の試験による確認が 必要であり，我々は現在完成品を用いてその試験を実 施中である．抄䟿の時点で約 200 日余りを経過してい るが，ほぼ加速寿命試験で得られた予測值と同じ変化 が認められている.

36. パーソナルコンピュータを使用した麻醉器 およひ気化器の制御システムの開発

シチズン時計 技術研究所

児 新毅

日本齿科大 麻酶科

高橋誠治住友雅人 古屋英哹

次代の麻醉を考える上でニンピュータの応用は避け て通れないものと考え, 麻醉実務の省力化および安全 性の向上を計るために種々な方面から取組んできた.

今回はその一つである麻醉器および気化器のパーソ ナルコンピュータによる制御システムを紹介する.

本システムの構成は，

(1)マイクロコンピュータ制御麻酔器

(2)設定篧度自動気化器

(3)麻酔深度モニター（フィンランド・デーテックス社 製A BM)

(4)麻酔ガス摆度計（フィンランド・デーテックス社製 NORMAC，スウェーデン・エングストロース社製 EMMA)

(5)パーソナルコンピュータ（NEC PC 9801-M 2)

(6)その他モニター機器

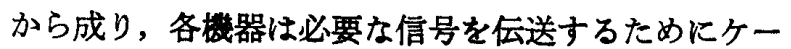
ブル線， R S-232C 通信線で接続されている.

この制御方法での役割分担は.

(1)マイクロコンピュータ制御麻酔器および設定㩐度自 動気化器は設定データを受け, 各制御成分を一定に 保つ。

(2)麻酔深度モニターおよび生体監視装置そして麻酔ガ ス濃度計は各々の患者の麻酔状況および麻酔ガス港 度を把握し，そのデータをパーソナルコンピュータ へ伝送する。

(3)パーソナルコンピュータは患者の生体反応および麻 醉ガス却度值から麻酔器および設定湦度自動気化器 の設定データを作成する．あるいは正常值を逸脱し た場合，警告を発する。

本システムを臨床応用した結果は一応成功といえる ものであった. しかし現在のところ制御值の決定は市 販の各種モニター機器に依存しており, その精度に左 右される. したがって安定性の上でまだ多くの問題点 があると思われた，逆にいえば本制御システムは確立 されており, 今後モニター機器の安定性の向上は目に 見えているので十分臨床応用に耐えられるものへの発 展が期待できる。 